\title{
Manajemen Kepala Sekolah dalam Meningkatkan Kinerja Mengajar Guru di MTs Assasul Islamiyah dan MTs Sabilul Huda Kabupaten Sukabumi
}

\author{
Abdullah Syaiful' ${ }^{1}$, Ricky Yoseptry ${ }^{2}$, Faiz Karim Fatkhullah ${ }^{3}$ \\ 1,2,3Sekolah Pascasarjana, Universitas Islam Nusantara Bandung, Indonesia \\ E-mail:dije2012@gmail.com, rickyyoseptry01@gmail.com, fkfatkhullah@gmail.com
}

\begin{abstract}
Article Info
Abstract

Article History

Received: 2021-12-27

Revised: 2022-01-22

Published: 2022-02-04

The purpose of this study was to describe the management of madrasah principals in improving the teaching performance of teachers at MTs Assasul Islamiyah and MTs Sabilul Huda, Sukabumi Regency. Leadership that has a vision (Visionary Leadership) is leadership whose main work is focused on engineering a future that is full of challenges, becomes a superior agent of change and determines the direction of the

Keywords:

Management;

Head of Madrasah;

Teaching Performance; Teacher. organization who knows priorities, becomes a professional trainer and can guide other personnel. towards the expected professionalism. This study uses a qualitative approach with a descriptive study method. The subjects in this study were the Head of Madrasah, Deputy Head of Madrasah for Curriculum, Teachers and Students. Based on the results of the research, the role of the Head of Madrasah in improving student achievement has been very good, it can be seen from the Head of the Madrasah who is responsible for all activities in the Madrasa. Learning achievement increases or not depends on the management of the Madrasah Principal because the Madrasah Head is the highest leader in the madrasa.
\end{abstract}

\begin{tabular}{l}
\hline Artikel Info \\
\hline Sejarah Artikel \\
Diterima: $2021-12-27$ \\
Direvisi: $2022-01-22$ \\
Dipublikasi: $2022-02-04$
\end{tabular}

Kata kunci:

Peranan;

Kepala Madrasah; Kinerja Mengajar; Guru.

\begin{abstract}
Abstrak
Tujuan penelitian ini adalah Untuk mendeskripsikan tentang manajemen kepala madrasah dalam meningkatkan kinerja mengajar guru di MTs Assasul Islamiyah dan MTs Sabilul Huda Kabupaten Sukabumi. Kepemimpinan yang memiliki visi (Visionary Leadership) yaitu kepemimpinan yang kerja pokoknya difokuskan pada rekayasa masa depan yang penuh tantangan, menjadi agen perubahan (Agent Of Change) yang unggul dan menjadi penentu arah organisasi yang tahu perioritas, menjadi pelatih yang profesional dan dapat membimbing personil lainya ke arah profesionalisme yang diharapkan. Penelitian ini menggunakan pendekatan kualitatif dengan metode studi deskriptif, Subjek dalam penelitian ini adalah Kepala Madrasah, Wakil Kepala Madrasah Bidang Kurikulum, Guru dan Siswa. Berdasarkan hasil penelitian peran Kepala Madrasah dalam meningkatkan prestasi belajar siswa sudah sangat baik itu bisa di lihat dari Kepala Madrasah bertanggung jawab terhadap semua kegiatan di Madrasah. Prestasi belajar meningkat atau tidak tergantung pada manajemen Kepala Madrasah karena Kepala Madrasah merupakan pimpinan tertinggi di madrasah.
\end{abstract}

\section{PENDAHULUAN}

Kepemimpinan merupakan aspek yang penting dalam sekolah, disamping kepemimpinan ada pula pendidikan yang merupakan bagian terpenting dari proses pembangunan nasional yang ikut menentukan pertumbuhan ekonomi suatu negara. Pendidikan juga merupakan investasi dari pengembangan sumber daya manusia, dimana peningkatan kecakapan dan kemampuan diyakini sebagai faktor pendukung upaya manusia dalam mengarungi kehidupan yang penuh dengan ketidak pastian, dalam hal ini pendidikan dalam konteks ekonomi daerah diharapkan dapat mengambil peran dalam mewujudkan fungsi dan tujuan pendidikan nasional yang tertuang dalam Undang-Undang RI Nomor 20 Tahun 2003 tentang Sistem Pendidikan Nasional Pasal 3 disebutkan bahwa "Pendidikan
Nasional berfungsi mengembangkan kemampuan dan membentuk watak serta peradaban bangsa yang bermartabat dalam rangka mencerdaskan kehidupan bangsa, bertujuan untuk berkembangnya potensi peserta didik agar menjadi manusia yang beriman dan bertaqwa kepada Tuhan Yang Maha Esa, berakhlak mulia, sehat, berilmu, cakap, kreatif, mandiri dan menjadi warga negara yang demokratis serta bertanggung jawab".

Untuk mewujudkan fungsi dan tujuan pendidikan nasional tersebut dalam tatanan mikro harus dihasilkan sumber daya manusia yang berkualitas dan profesional sesuai dengan fungsi dan tujuan pendidikan yang tercantum dalam Sisdiknas pasal 3 diatas, termasuk di dalamnya kebutuhan kerja dan respon terhadap perubahan masyarakat setempat, dimana dalam konteks daerah harus mampu meningkatkan 
mutu layanan jasa yang ditawarkan kepada masyarakat, sesuai dengan kebutuhan lokal dan tantangan global, dalam mempersiapkan sumber daya manusia yang berkualitas dan profesional, pendidikan tidak hanya terfokus pada kebutuhan material, tetapi harus menyentuh dasar untuk memberikan watak pada visi dan misi pendidikan, yaitu perhatian mendalam pada etika moral dan spiritual yang luhur. Oleh karena itu lembaga pendidikan hendaknya harus dikelola secara profesional dengan manajemen yang baik oleh pendidik dan tenaga pendidik, mengingat sebagaimana diketahui bahwa lembaga pendidikan merupakan salah satu prioritas pembangunan nasional yang kaitannya dengan pengembangan sumber daya manusia menyangkut peningkatan mutu pada setiap jenis dan jenjang pendidikan. Kepemimpinan dalam lembaga pendidikan khususnya sekolah dipimpin oleh kepala sekolah yang merupakan pemimpin di sekolah, baik sebagai pemimpin bagi para guru maupun sebagai manajer dalam manajemen sekolah sehingga kepala sekolah harus mampu bertindak sebagai seorang manajer dan pemimpin yang efektif dalam mengelola segala kegiatan sekolah agar semua potensi sekolah bisa berfungsi dan berjalan secara optimal dengan adanya manajemen dari kepala sekolah tersebut.

Kepala sekolah sebagai pemimpin di sekolah tersebut harus memiliki kepiawaian dalam menghasilkan tatanan yang cerdas spiritual, sosial dan intelegensi untuk memenuhi tuntutan era globalisasi saat ini, karena itu kepala sekolah di MTs. Assasul Islamiyah dan MTs. Sabilul Huda Kecamatan Cikembar Kabupaten Sukabumi secara rutin melaksanakan kegiatan supervisi dan Musyawarah Guru Mata Pelajaran (MGMP) pada setiap guru mata pelajaran untuk bisa menjalankan tugasnya dengan maksimal dalam meningkatkan kinerja mengajar guru, ada beberapa permasalahan yang muncul diantaranya yaitu kurangnya kualitas guru dalam menyampaikan materi pembelajaran kepada para siswa, kurangnya kompetensi pada guru dalam bidang mata pelajaran, karena gurunya tidak hanya mengampu satu mata pelajaran yakni disesuaikan dengan kebutuham pengajar dalam mata pelajarannya, contohnya pembagian tugas mengajar disesuaikan dengan kebutuhan mata pelajaran yang diampunya.

Berdasarkan hasil penelitian ditemukan beberapa masalah-masalah pembinaan kepala sekolah dalam kinerja guru yaitu pembinaan kinerja guru belum sepenuhnya dilaksanakan secara berkesinambunga, masih terlihat adanya guru yang belum maksimal dalam menjalankan tugasnya sesuai dengan tupoksi yang sudah dibuat oleh sekolah, belum nampak keprofesionalannya dan kinerja yang baik, seperti tidak semua guru melakukan analisis penilaian, copy paste dalam membuat rencana pembelajaran, penggunaan metode pembelajaran yang kurang variatif, wali kelas yang kurang kordinasi dengan wakil kepala bidang kesiswaan maupun guru BP yang kurang memberikan penyuluhan dan bimbingan kepada siswa. Fenomena dilapangan dari hasil wawancara dengan guru MTs Assasul Islamiyah dan MTs Sabilul Huda Kabupaten Sukabum menunjukkan, umumnya perilaku pembelajaran guru masih terbatas pada pengertian makna mengajar, di mana proses pengajaran bersifat searah dari guru kepada peserta didiknya. Akibatnya, pembelajaran seringakali bersifat monoton, kurang menarik dan kurang memberikan motivasi, serta cenderung menimbulkan sikap pasif pada peserta didik.

Berdasarkan pengamatan penulis pada MTs Assasul Islamiyah dan MTs Sabilul Huda Kabupaten Sukabumi, terlihat bahwa kualitas mengajar guru masih kurang baik, cara pengajaran guru yang kurang menunjukkan perubahan yang berarti, walaupun sudah sekian kali dilakukan pelatihan. Guru sering kali hanya menggunakan metode ceramah dalam pembelajaran dan jarang menggunakan media penunjang dalam pembelajaran serta sarana dan prasarana dalam pembelajaran kurang dan belum lengkap, ditambah dengan kurang disiplinnya siswa di MTs Assasul Islamiyah dan MTs Sabilul Huda Kabupaten Sukabum yang sering terlambat masuk kelas, tertidur pada saat pembelajaran dan kurang fokus saat pembelajaran, dari keadaan kondisi yang terjadi diatas peneliti memfokuskan pada Manajemen Kepala Sekolah Dalam Meningkatkan Kinerja Mengajar Guru, karena peneliti tertarik untuk mengetahui sejauh mana manajemen kepala sekolah dalam mengelola dan menggerakkan para pendidik dilembaga yang dipimpinnya sekaligus menjelaskan secara gamblang mengenai program peningkatan kinerja mengajar guru yang dilakukan oleh kepala sekolah, yaitu manajerial kepala sekolah terkait dengan pembinaan kepala sekolah terhadap peningkatan kinerja mengajar guru dalam mengembangkan proses belajar mengajar di kedua lembaga tersebut. 


\section{METODE PENELITIAN}

Penelitian ini menggunakan pendekatan kualitatif dengan metode studi deskriptif karena ada beberapa informasi yang bisa diperoleh bagi pemecahan masalah. Pertama informasi keadaan saat ini (present condition), kedua informasi yang kita inginkan (what we may want) dan ketiga bagaimana sampai bisa kesana, bagaimana mencapainya (how to get there), sedangkan jenis penelitian deskriptif yang dipilih adalah studi kasus (case study). Moleong setelah melakukan analisis terhadap beberapa definisi penelitian kualitatif kemudian membuat definisi sendiri sebagai sisntesis dari pokok-pokok pengertian penelitian kualitatif, menurut Moleong penelitian kualitatif adalah penelitian yang bermaksud untuk memahami fenomena tentang apa yang dialami oleh subjek penelitian misalnya perilaku, persepsi, motivasi, tindakan, dll. secara holistic, dan dengan cara deskripsi dalam bentuk katakata dan bahasa, pada suatu konteks khusus yang alamiah dan dengan memanfaatkan berbagai metode alamiah. Penelitian deskriptif bertujuan untuk memaparkan secara sitematis faktual dan akurat mengenai fakta-fakta dan sifat-sifat populasi tertentu, penilaian ini umumnya mengunakan pendekatan empiri-rasional, artinya data dikumpulkan sesuai dengan tujuan dan secara rasional disusun kesimpulan-kesimpulan yang dapat ditarik dari data yang terkumpul. Teknik pengumpulan data yang digunakan yaitu observasi, wawancara, studi dokumentasi dan triangulasi, adapun penelitian yang dilakukan oleh peneliti mengambil lokasi di MTs Assasul Islamiyah dan MTs Sabilul Huda Kabupaten Sukabumi.

\section{HASIL DAN PEMBAHASAN}

Hasil wawancara, observasi, dan dokumentasi penelitian menunjukan bahwa perencanaan peranan kepala madrasah di MTs Assasul Islamiyah dilakukan melalui:

1. Perencanaan peranan kepala madrasah sejalan dengan visi dan misi yang dikembangkan oleh Madrasah dan kegiatan yang dilalukan untuk peningkatan Kinerja Mengajar Guru bersama guru adalah pengadaan media pembelajaran seperti buku paket dan media lainya, hal itu bertujuan agar terwujudnya Visi dan misi Madrasah. Madrasah juga menyusun RKTM sesuai dengan bidang masing-masing, kami juga merencanakan pengembangan kompetensi guru melalui Diklat, PKG dan MGMP.
2. Merumuskan tujuan peranan kepala madrasah dalam meningkatkan kinerja mengajar guru yang ingin dicapai MTs Assasul Islamiyah, dalam menentukan tujuan, pengamatan peneliti selama dilapangan menunjukan bahwa dalam merencanakan peningkatan kinerja mengajar guru, pihak madrasah terlebih dahulu menentukan tujuan yang diinginkan. Pada dasarnya tujuan terfokus pada tercapainya tujuan dari kinerja mengajar guru, sebagai guru harus mempersiapkan dan juga merencanakan dengan matang, apa yang akan disampaikan kepada para siswanya. Hal ini penting karena perencanaan berperan besar dalam proses pembelajaran, kegagalan dalam hal apapun seringkali disebabkan karena perencanaan yang buruk, kami juga memasukan tujuan pembelajaran dalam setiap RPP yang kami buat. Tujuan tersebut sesuai dengan visi, misi dan tujuan madrasah.

3. MTs Asssul Islamiyah Kabupaten Sukabumi menyusun kalender pendidikan sesuai dengan kebutuhan daerah, karakteristik madrasah, kebutuhan peserta didik, dan masyarakat, dengan memperhatikan kalender pendidikan yang dimuat dalam Standar Isi. Kalender pendidikan berisi Minggu efektif, Jam efektif, Hari libur keagamaan, Hari libur nasional, Ulangan harian, Penilaian Akhir Semester, Penilaian Akhir Tahun, Ujian Madrasah, Ujian Nasional dan Kalender Kegiatan Madrasah. Kalender pendidikaan MTs Assasul Islamiyah Kabupaten Sukabumi disusun dengan berpedoman kalender pendidikan yang dikeluarkan oleh Kantor Wilayah Kementerian Agama Provinsi Jawa Barat untuk tahun pelajaran 2019/2020.

Pelaksanaan peranan kepala madrasah di MTs Assasul Islamiyah Kabupaten Sukabumi dalam rangka meningkatkan kinerja mengajar guru diantaranya sebagai berikut:

1. Kegiatan yang bersifat rutin dan berjalan dengan baik terkait dengan kompetensi guru.

2. Kegiatan Belajar Mengajar (KBM) Madrasah Tsanawiyah Assasul Islamiyah menyelenggarakan program pendidikan dengan menggunakan sistem paket.

3. Dalam pengelolaan Penerimaan Peserta Didik Baru (PPDB) ini dilaksanakan sesuai dengan juknis dan juklak, di madrasah ini diadakan penyeleksian sesuai dengan peraturan yang ada dimana sebelum kelulusan itu kami adakan tes kemampuan dasar yaitu basicnya 
adalah agama sementara anak-anak kami bukan dari background yang sama.

Evaluasi merupakan proses yang amat penting untuk mengetahui manfaat, kualitas, kebermaknaan, jumlah, tingkat dan kondisi dari situasi yang ada, evaluasi peranan kepala madrasah dilakukan secara periodic. Hasilnya digunakan untuk pengambilan keputusan dalam rangka pengembangan dan peningkatan Kinerja Mengajar Guru, setiap melakukan kegiatan monitoring, Kepala Madrasah menuliskannya dalam bentuk laporan supervisi yang kemudian akan disampaikannya kepada guru-guru yang bersangkutan dalam bentuk laporan evaluasi guru, hal ini dilakukan untuk meningkatkan Kinerja Mengajar Guru untuk mendapatkan pendidikan yang baik sekaligus menjalankan perannya dalam bidang controling dan evaluasi, faktor Penghambat Peranan kepala madrasah dalam meningkatkan kinerja mengajar guru yaitu guru sebagai pendidik dan pengajar, Orang tua dan Lingkungan.

Proses perencanaan dalam peningkatan Kinerja Mengajar Guru di MTs Sabilul Huda Kabupaten Sukabumi melibatkan semua pihak mulai dari Ketua Yayasan, Kepala Lembaga yang berada dibawah Yayasan Sabilul Huda Sukabumi, setiap awal tahun pengurus yayasan selalu mengadakan rapat koordinasi dengan semua pimpinan lembaga yang berada dibawah Yayasan Sabilul Huda Sukabumi untuk menentukan program selama satu tahun kedepan, kemudian secara teknis dan terperinci dijabarkan oleh lembaga masing-masing termasuk MTs Sabilul Huda Kabupaten Sukabumi, dalam penyusunan program selama satu tahun tetap mengacu pada Visi dan Misi MTs Sabilul Huda Kabupaten Sukabumi. Identifikasi perencanaan dilakukan agar tujuan yang telah direncanakan dapat tercapai dengan baik, Identifikasi terkait program pendidikan terpadu dilakukan dengan mengidentifikasi pendukung dan penghambat di MTs Sabilul Huda Kabupaten Sukabumi, dukungan yang didapat oleh MTs Sabilul Huda Kabupaten Sukabumi berupa dukungan pendidik, tenaga kependidikan, wali siswa dan masyarakat sekitar.

MTs Sabilul Huda Kabupaten Sukabumi mensosialisasikan kepada masyarakat tentang adanya program pendidikan terpadu agar masyarakat mau menyekolahkan putra putrinya yang di MTs Sabilul Huda Kabupaten Sukabumi, identifikasi dalam pendidikan juga dilakukan saat penerimaan peserta didik baru agar madrasah mengetahui kebutuhan yang dimiliki peserta didik, sehingga dapat merencanakan halhal yang akan dilakukan agar tujuan yang ditetapkan dapat tercapai. Pengorganisaisian MTs Sabilul Huda Kabupaten Sukabumi, Kepala Madrasah Sebagai penanggung jawab, kemudian wakil kepala Madrasah bidang Kurikulum sebagai koordinator, adapun kegiatan pembinaan siswa dalam peningkatan prestasi belajar, dilakukan oleh guru di madrasah, ustadz, wali asuh dan ospa di lingkungan pondok pesantren, Aktivitas pengorganisasian selalu dilakukan dalam suatu lembaga pendidikan, dimaksudkan untuk menertibkan dan mengorganisir atau mengatur lembaga tersebut. Pembinaan terhadap siswa dalam peningkatan Kinerja Mengajar Guru di pondok pesantren dilakukan oleh semua pihak baik itu guru, wali asuh dan ospa, Koordinasi akan dilakukan oleh kepala madrasah dengan bagian keamanan atau wali asuh di pondok pesantren, sehingga terjadi sinkronisasi program, karena tugas madrasah hanya terbatas sampai kegiatan belajar formal, selebihnya menjadi tanggung jawab pengurus pondok pesantren. Kepala Madrasah membagi tugas pada pendidik dan tenaga kependidikan pada awal tahun pelajara, guru kelas dan wali kelas dapat berubah-ubah sesuai dengan Surat Keterangan (SK) yang Kepala madrasah berikan pada pendidik dan tenaga kependidikan, pembagian tugas peningkatan Kinerja Mengajar Guru Kepala MTs Sabilul Huda Kabupaten Sukabumi memberikan tugas sepenuhnya pada guru.

Dalam pelaksanaan manajmen kepala madrasah untuk peningkatan Kinerja Mengajar Guru, MTs Sabilul Huda Kabupaten Sukabumi meng-gunakan konsep kurikulum Nasional yang mengacu pada trilogi Pondok Pesantren yaitu berakhlak mulia, menguasai ilmu pengetahuan dan teknologi, untuk meningkakan Kinerja Mengajar Guru maka pelaksanaan dalam proses pembelajaran disetiap kelas terdapat 1 wali kelas, pembelajaran mata pelajaran lainnya dipegang guru bidang studi, dari kelas VII, VIII dan IX siswa dipisah berdasarkan jenis kelamin. Proses pembelajaran diserahkan kepada guru bidang studi masing-masing dengan tetap mengacu kepada RPP yang sudah dibuat. Evaluasi merupakan proses yang amat penting untuk mengetahui manfaat, kualitas, kebermaknaan, jumlah, tingkat dan kondisi dari situasi yang ada, evaluasi manajemen Kepala Madrasah dilakukan secara periodik, hasilnya digunakan untuk pengambilan keputusan dalam rangka pengembangan dan peningkatan prestasi siswa. 
Sebagaimana tujuan dan arti pendidikan, kegiatan pembelajaran di MTs Assasul Islamiyah dan MTs Sabilul Huda Kabupaten Sukabumi senantiasa meng-integrasikan proses belajar mengajar dengan 6 sitem nilai yang ada pada Pendidikan kecakapan hidup antara lain:

1. Nilai Teologik (Rukun Iman, Rukun Islam, Tauhid, Ibadah, dan Ihsan) bisa dilihat di tujuan mata pelajaran pendidikan agama yaitu Membentuk peserta didik menjadi manusia yang beriman dan bertakwa kepada Allah SWT.

2. Nilai Etik-Hukum (Sopan, Ramah, Hormat, dan rendah Hati) dapat dilihat pada tujuan mata pelajaran pendidikan Kewarganegaraan yaitu Membentuk peserta didik menjadi warga negara yang memiliki wawasan dan rasa kebersamaan, cinta tanah air, serta bersikap dan berperilaku demokratis. Sopan, ramah, dan lain-lain.

3. Nilai Estetik (Bersih, Indah, Bagus, merdu, Cantik) dapat dilihat di tujuan mata pelajaran seni dan budaya yaitu Membentuk karakter peserta didik menjadi manusia yang memiliki rasa seni dan pemahaman budaya.

4. Nilai Logis-Rasional (Logika, Cocok antara Fakta dan kesimpulan, tepat, sesuai, jelas, nyata) bisa dilihat pada tujuan mata pelajaran matematika dan ilmu pengetahuan alam yaitu Mengembangkan pengetahuan, dan kemampuan analisis peserta didik terhadap lingkungan alam dan sekitarnya.

5. Nilai Fisik-Fisiologik (Tumbuh Berkembang, dewasa, sehat) dapat dilihat di tujuan pada mata pelajaran Pendidikan jasmani olah raga dan Kesehatan yaitu Membentuk karakter peserta didik agar sehat jasmani dan rohani, serta menumbuhkan rasa sportivitas.

6. Nilai Teleologik (Sesuai maksud dan tujuan, sesuai fungsi, Produktif, efektif, efisien) bisa dilihat pada tujuan mata pelajaran bahasa dan ilmu sosial yaitu Membentuk peserta didik mampu berkomunikasi secara efektif dan efisien sesuai dengan etika yang berlaku, baik secara lisan maupun tulisan dan mengembangkan pengetahuan, pemahaman, dan kemampuan analisis peserta didik terhadap kondisi sosial masyarakat.

Peranan Kepala Madrasah Dalam Meningkatkan Kinerja Mengajar Guru ditemukan bahwa setiap tahunnya kepala madrasah selalu membuat program peningkatan Kinerja Mengajar Guru, program tersebut dibuat sesuai dengan visi dan misi madrasah yang bertujuan untuk meningkatkan Kinerja Mengajar Guru,
Kepala madrasah sebagai penanggung jawab satuan pendidikan selalu melibatkan semua komponen madrasah dalam rangka perencanaan, pengoragnisasian, pelaksanaan dan mengevaluasi program madrasah. Ada beberapa program peningkatan kinerja guru untuk peningkatan Kinerja Mengajar Guru yang telah dilaksanakan diantaranya adalah program pelatihan guru, seminar, workshop, Musyawarah Guru Mata Pelajaran (MGMP), Kelompok Kerja Guru (KKG), pertemuan antar madrasah dan pemberian penghargaan kepada guru, suksesnya seorang kepala madrasah tentu harus diukur dengan program kerja madrasah yang telah disusun dan direncanakan, serta capaian hasil yang sesuai dengan perencanaan yang telah disusun dengan melibatkan seluruh stakeholder di madrasah.

\section{SIMPULAN DAN SARAN}

\section{A. Simpulan}

Berdasarkan hasil penelitian dan pembahasan pada bab sebelumnya, maka simpulan yang dapat peneliti berikan adalah sebagai berikut:

1. Perencanaan Kepala madrasah dalam upaya peningkatan prestasi siswa sudah berjalan cukup baik itu dimulai Rencana program manajemen Kepala Madrasah yang tertuang dalam visi, misi, tujuan dan RKTM (Rencana Kerja Tahunan Madrasah). Perencanaan tersebut merupakan bagian dari program kerja Kepala Madrasah bersama dengan guru dan orang tua siswa. Kepala Madrasah sebagai manajer dalam pelaksanaan manajemen Kepala Madrasah, memberikan kesempatan kepada tenaga kependidikan untuk meningkatkan profesinya dan mendorong keterlibatan seluruh tenaga kependidikan dalam berbagai kegiatan yang menunjang pengelolaan program sekolah.

2. Pengorganisasian sudah berjalan dengan baik, karena Kepala Madrasah di kedua sekolah tersebut sudah melakukan pengoraganisasian dilakukan oleh pengurus yang bertugas untuk menerjemahkan dan menjabarkan arah kebijakan madrasah dan Yayasan dalam meningkatkan kinerja mengajar guru, pembagian kerja di kedua madrasah ini sudah terperinci karena adanya program kerja yang sudah berjalan selama ini.

3. Pelaksanaan dalam peningkatan prestrasi belajar siswa dikedua madrasah tersebut 
sudah berjalan dengan baik walaupun masih ada sedikit hambatan mengenai kesesuaian ijazah guru dengan tugas yang diambil yang mengakibatkan pembelajaran kurang efektif, seluruh rencana program yang telah ditetapkan melalui rapat ataupun musyawarah dalam pelaksanaannya sesuai dengan struktur organisasi sekolah dan jadwal yang telah ditetapkan.

4. Kepala Madrasah juga melakukan pengawasan dengan supervisi sehingga dapat mengetahui bagaimana kinerja guru dalam pembelajaran dikelas, sehingga dapat dijadikan evaluasi untuk kedepannya agar lebih baik. Guru mempunyai tanggung jawab untuk mengawasi peserta didik disaat pembelajaran berlangsung. Pengawasan yang dilakukan oleh kepala Madrasah dalam hal meninjau kembali program kerja yang telah dilaksanakan, bertujuan untuk meningkatkan dan/atau mempertahankan program kegiatan peningkatan kinerja mengajar guru.

5. Faktor pendukung yang mempengaruhi manajemen Kepala Madrsah dalam meningkatkan kinerja mengajar guru terdiri dari faktor pendidik, sarana dan prasarana, biaya, kurikulum, lingkungan, Optimalisasi Kejasama Kepala Madrasah, Yayasan dan Orang tua siswa.

6. Sedangkan faktor penghambat adalah sarana dan prasarana yang belum memadai, guru mengajar tidak sesuai dengan kualifikasi akademik dan pengawsan orang tua.

Strategi Kepala Madrasah dalam meningkatkan kinerja mengajar guru adalah Kepala Madrasah sering memberikan kesempatan kepada guru untuk mengembangkan diri dengan memberikan kesempatan melanjutkan pendidikan ke jenjang yang lebih tinggi, serta mengikutkan guru dalam pelatihan-pelatihan, seminar ataupun KKG dan MGMP, strategi yang tepat untuk mengatasi masalah yang berkaitan dengan sarana prasarana, sebaiknya pihak sekolah mengalokasikan anggaran khusus tiap tahun agar sarana prasarana yang ada dapat berkualitas dan dapat menunjang tercapainya tujuan pembelajaran. Pemberdayaan potensi siswa melalui pemanduan dan pembimbingan minat dan bakat yang pelaksanaan kegiatannya dilakukan di luar jam belajar mengajar, serta pengontrolannya dipantau langsung oleh Kepala Madrasah.

\section{B. Saran}

Berdasarkan hasil penelitian dan pembahasan pada bab sebelumnya, maka rekomendasi yang dapat peneliti berikan adalah sebagai berikut:

1. Kepala Madrasah, dalam merencanakan program bersama warga sekolah yang selama ini telah berlangsung sudah menjadi karakter dan kekuatan sekolah sebaiknya dipertahankan dan ditingkatkan. Untuk meningkatkan prestasi sekolah dalam pelaksanaannya adalah dengan memanfaatkan berbagai sisi kekuatan yang dimiliki para Kedua guru, siswa, dan orang tua siswa. Pengontrolan dalam bentuk supervisi kepada para guru yang setiap hari berhadapan dengan peserta didik dengan segala problematikanya, dapat memberikan kontribusi bagi pengembangan program untuk meningkatkan kinerja mengajar guru.

2. Guru Tetap menjalin kerjasama yang baik dengan Kepala Madrasah dan guru lain untuk menunjang pelaksanaan strategi dalam peningkatan kinerja mengajar guru, tingkatkan kemampuan diri dalam mengelola pembelajaran dengan model pembelajaran yang aktif, kreatif, inovatif, efektif dan menyenangkan.

3. Untuk siswa penelitian ini diharapkan dapat memberikan pemahaman yang lebih kepada siwa dan juga diikuti oleh meningkatkan keaktifan belajar siswa sebagai unsur dasar untuk meningkatkan prestasi belajar dan melanjutkan kejenjang berikutnya.

4. Orang tua siwa dengan terbatasnya waktu anak di sekolah, maka orang tua sebagai pendidik pertama dan utama hendaknya mengubah paradigma tentang bagaimana anak belajar dan memperoleh pengetahuan, komunikasi dan koordinasi perlu dibangun dalam upaya peningkatan kinerja mengajar guru.

5. Untuk Peneliti lain, penelitian ini diharapkan menjadi alternatif referensi untuk mengembangkan penelitian Manajemen Kepala Madrasah dalam Meningkatkan Kinerja mengajar guru yang lebih lanjut dan memperluas pengetahuan bagi pembaca tentang pentingnya penerapan manajemen Kepala Madrasah dalam meningkatkan kinerja mengajar guru. 
DAFTAR RUJUKAN

Afroni, Ahmad. (2009). Kompetensi Kepala Sekolah Sebagai Supervisor

Pemebelajaran Dalam Upaya Peningkatan Kopetensi Guru, Forum Tarbiyah, Vol 7. No 1.

Arifin, Daeng (2010). Manajemen Pembelajaran Efektif, Bandung:

Pustaka AlKasyaf.

Ati Kurniati (2016). Manajemen Kepala Sekolah Untuk Meningkatkan Kinerja Guru Dalam Rangka Mengembangkan Prestasi Belajar Siswa (Studi Kasus di SLB Al Hikmah, SLB Rama Sejahtera dan SLB Ngumprah Raya Kabupaten Bandung Barat), Tesis : Bandung : Uniiversitas Islam Bandung.

DEPDIKNAS. (2016). Kamus Besar Bahasa Indonesia, Jakarta: Balai Pustaka.

E. Mulyasa. (2015). Implementasi Kurikulum 2013. Bandung: PT Remaja Rosdakarya.

Elis Juwita Purnamawati (2013). Kepemimpinan Manajerial Kepala Sekolah Dalam Peningkatan Kinerja Guru (Studi Kasis di SMKN 6, SMKN 7 dan SMKN 9 Bandung), Tesis : Bandung : Uniiversitas Islam Bandung.

George.R.Terry. (1993). Prinsip-prinsip Manajemen, Terj. J. Smith, Jakarta: Bumi Aksara.

Hamdayana, Jumanta (2017). Model Dan Metode Pembelajaran Kreatif Dan Berkarakter, Bogor : Ghalia Indonesia.

Handoko, T. Hani. 2014. Manajemen Personalia dan Sumber Daya Manusia. BPFE, Yogyakarta.

Harahap, Sofyan Syafri. 2013. 1992) Akuntansi Pengawasan dan Manajemen dalam Perspektif Islam, Jakarta: Fakultas Ekonomi Universitas Trisakti

Hermino, Agustinus (2014). Manajemen Kurikulum Berbasis Karakter : Konsep, Pendekatan Dan Aplikasi, Bandung : Alfabeta.

Isnaeni, Rokhayati. (2014). Perkembangan Teori Manajemen Dari Scientific Management Hingga Era Modern Suatu Tinjauan
Pustaka. Jurnal Ekonomi dan Bisnis. Vol 15 No 2.

Juliantoro, Muhamad (2017). Peran Kepala Sekolah dalam Meningkatkan Mutu Pendidikan. Jurnal Al-Hikmah, Vol 5 No. 2.

Karweti, Engkay. (2010). Pengaruh Kemampuan Manajeriar Kepala Sekolah dan Faktor yang Mempengaruhi Motivasi Kerja Terhadap Guru SLB di Kab. Subang. Jurnal Penelitian Pendidikan No. 11 Volume 2.

Khori, Ahmad. (2015). Kepemimpinan Dalam Perpektif Filsafat. Jurnal NER No 4 Volume 1.

Kristianty, Theresia. (2005). Peningkatan Mutu Pendidikan Terpadu Cara Deming, Jurnal Pendididikan Penabur No. 4.

Kuntjojo, (2009). Metodologi Penelitian, Makalah Metodologi Penelitian.

Lestari, Sri (2016). Pengaruh Kepemimpinan Kepala Sekolah dan Kinerja Guru Terhadap Prestasi Siswa, Jurnal Satya Widia, Vol 32, No 2.

Lisnawati Rita (2017). Fungsi Kepala Sekolah, Motivasi dan Kinerja Guru. Jurnal Pendidikan. Volume 2 No. 2.

Ma'ruf, F. (2021). Pengembangan Game Edukasi Berbasis Flash Sebagai Sarana Belajar Siswa PAUD. Ainara Journal Uurnal Penelitian Dan PKM Bidang Ilmu Pendidikan), 2(3), 143-147. https://doi.org/10.54371/ainj.v2i3.68

Maisaro Atik dkk. 2018. Manajemen Program Penguatan Pendidikan Karakter di Sekolah Dasar. Jurnal Administrasi dan Manajemen Pendidikan. Volume 1 Nomor 3.

Majid, Abdul (2009). Perencanaan Pembelajaran : Mengembangkan Standar Kompetensi Guru, Bandung : PT Remaja Rosdakarya.

Malayu S.P. Hasibuan, (2007). Manajemen: Dasar, Pengertian dan Masalah, Jakarta: Bumi Aksara.

Mardapi Djemari (2009). Evaluasi Penerapan Ujian Akhir Sekolah Dasar Berbasis Standar Nasional. Jurnal Penelitian dan Evaluasi Pendidikan. Volume 2 No. 2. 
Moekiyat, (1980). Kamus Management, Bandung: Alumni.

Moleong, Lexy J (2019). Metodologi Penelitian Kualitatif, Bandung : PT Remaja Rosdakarya.

Mustamin, Hasmiah. Sulasteri, Sri. (2013). Faktor-Faktor Yang Mempengaruhi Prestasi Belajar Mahasiswa Jurusan Pendidikan Matematika Fakultas Tarbiyah Dan Keguruan UIN Aluddin Makasar. Jurnal Matematika dan Pembelajaran (MAPAN). No.1 Volume I.

Oktavia, Yanti. (2014). Usaha Kepala Sekolah Dalam Meningkatkan Kreativitas Guru Dalam Pembelajaran Disekolah Dasar, Jurnal Administrasi Pendidikan No 1 Volume 2.

Pianda, Didi (2018). Kinerja Guru : Kompetensi Guru, Motivasi Kerja, Kepemimpinan Kepala Sekolah, Sukabumi : CV.Jejak.

Purwanto, Ngalim M. (1998). Administrasi Dan Supervisi Pendidikan, Bandung: Remaja Rosdakarya.

Rusmiati. (2017). Pengaruh Minat Belajar Terhadap Prestasi Belajar Bidang Studi Ekonomi Siswa Ma Al Fattah Sumbermulyo. No.1 Volume I.

Sagala, Saiful. (2003). Konsep dan Makna Pembelajaran, Bandung: Alfabeta.

Sallis, Edward (2012). Manajemen Mutu Pendidikan, Terj Dr. Ahmad Ali Riyadi, Yoyakarta : IRCiSOD.

Sanusi, Achmad. (2017). Sistem Nilai : Alternatif Wajah-Wajah Pendidikan, Bandung : Nuansa Cendikia.

Siagian, 2013. Manajemen Sumber daya Manusia, Jakarta : Bumi Aksara.

Siagian, Sondang P. (1984). Filsafat Administrasi, Jakarta: Gunung Agung.

Siburian, Tiur Asi. (2013). Metodologi Penelitian Manajemen Pendidikan, Medan : Unimed.

Slameto. 2010. Belajar dan faktor-faktor yang Mempengaruhinya. Jakarta:

PT. Rineka Cipta.
Sri (2016). Pengaruh Kepemimpinan Kepala Sekolah dan Kinerja Guru Terhadap Prestasi Siswa, Jurnal Satya Widia, Vol 32, No 2.

Sumarsih (2009). Implementasi Teori Pembelajaran Konstruktivistik Dalam Pembelajaran Mata Kuliah Dasar-Dasar Bisnis. Jurnal Pendidikan Akuntasi Indonesia No.1 Volume VIII.

Supriyanto (2015). Manajemen Supervisi Kepala Sekolah Dalam Peningkatan Kinerja Guru (Studi Kasus Pada SMP Negeri 2 Dan SMP Negeri 3 Slawi Kabupaten Tegal), Tesis Bandung : Uniiversitas Islam Bandung.

Susanto, Ahamd (2016). Manajemen Peningkatan Kinerja Guru : Konsep, Strategi dan Implementasi, Depok : Prenadamedia Group.

Syamsul, Herawati, (2007). Penerapan Kepemimpinan Kepala Sekolah Dalam Meningkatkan Kinerja Guru Pada Jenjang Sekolah Menengah Pertama (SMP). Juranal Idaarah, No.2, Volume I.

Syarifudin. 2011. Manajemen Pendidikan. Jakarta: Diadit Media.

Tafsir, Ahmad. (2015). Ilmu Pendidikan Sugiyono. (2013). Metode Penelitian Pendidikan Pendekatan Kuantitatif, Kualitatif, dan $R \& D$. Bandung : Alfabeta.

Tim Dosen Administrasi Pendidikan Universitas Pendidikan Indonesia, (2013). Manajemen Pendidikan, Alfabeta, Bandung.

Tiroy Jonatha Panggabean, Wahyudi, Usman Radiana. Manajemen Kepala Sekolah Dalam Upaya Peningkatan Prestasi Di Sekolah Dasar. FKIP UNTAN. Pontianak.

Wati, Widya. (2010). Teori Belajar dan Pembelajaran. Makalah Starategi Belajar Mengajar. Universitas Negeri Padang.

Yayat M. Herujito. (2001). Dasar-Dasar Manajemen, Jakarta : Grafindo Persada. 